\title{
BRACHIARIA SPECIES AFFECTING SOIL NITRIFICATION $^{(1)}$
}

\author{
Adalton Mazetti Fernandes ${ }^{(2)}$, Gabriel José Massoni de \\ Andrade $^{(3)}$, Emerson de Freitas Cordova de Souza ${ }^{(3)}$ \& Ciro \\ Antonio Rosolem ${ }^{(4)}$
}

\section{SUMMARY}

Nitrification can lead to substantial losses of the applied $\mathrm{N}$ through nitrate leaching and $\mathrm{N}_{2} \mathrm{O}$ emission. The regulation of nitrification may be a strategy to improve fertilizer $\mathrm{N}$ recovery and increase its agronomic efficiency. The objective of this study was to evaluate the inhibiting capacity of nitrification in soil by Brachiaria species. The greenhouse experiment was conducted using pots with $10 \mathrm{dm}^{3}$ of a Red Latosol sample. The treatments consisted of the cultivation of three forage species (Brachiaria brizantha, B. ruziziensis and B. decumbens) and four $\mathrm{N}$ rates $(0,100,200$, and $300 \mathrm{mg} /$ pot), and the control (without plants). In the absence of the forage plants, all $\mathrm{N}$ fertilization levels raised the $\mathrm{N}^{-} \mathrm{NO}_{3}{ }^{-}$soil levels, as a result of nitrification. The mineralization of organic matter supplied much of the $\mathrm{N}$ requirement of the forage plants and nitrification was influenced in the rhizosphere of $B$. brizantha; however, this effect was not high enough to alter the $\mathrm{N}-\mathrm{NH}_{4}{ }^{+}$level in the total soil volume of the pot.

Index terms: ammonium, nitrate, nitrogen.

\section{RESUMO: ESPÉCIES DE BRAQUIÁRIAS ALTERANDO A NITRIFICAÇÃO NO SOLO}

O processo de nitrificação pode conduzir a perdas substanciais do nitrogênio aplicado por meio da lixiviação de nitrato e emissão de $\mathrm{N}_{2} \mathrm{O}$. A regulação da nitrificação pode ser uma

\footnotetext{
(1) Received for publication in November 26, 2010 and approved in June 6, 2011.

(2) Doutorandos em Agronomia (Agricultura), Faculdade de Ciências Agronômicas, Universidade Estadual Paulista -FCA/UNESP. Campus de Botucatu, Caixa Postal 237, CEP 18603-970 Botucatu (SP). E-mail: adalton@fca.unesp.br

${ }^{(3)}$ Mestre em Agronomia (Agricultura), Faculdade de Ciências Agronômicas, FCA/UNESP. E-mails: agrobiel@yahoo.com.br; emerson.cordova@hotmail.com

(4) Professor Titular do Departamento de Produção Vegetal, Faculdade de Ciências Agronômicas, FCA/UNESP. E-mail: rosolem@fca.unesp.br
} 


\begin{abstract}
estratégia para melhorar a recuperação do Ne aumentar sua eficiência agronômica. O objetivo deste trabalho foi avaliar a habilidade de espécies do gênero Brachiaria de inibir o processo de nitrificação no solo. O experimento foi realizado em casa de vegetação, em vasos contendo $10 \mathrm{dm}^{3}$ de um Latossolo Vermelho. Os tratamentos foram constituídos do cultivo de três espécies forrageiras (Brachiaria brizantha, B. ruziziensis $e$ B. decumbens) e quatro doses de $N(0,100,200$ e $300 \mathrm{mg} /$ vaso), além da testemunha (sem a presença das forrageiras). Na ausência do cultivo de forrageiras, todos os níveis de adubação nitrogenada proporcionaram maior teor de $\mathrm{N}_{-} \mathrm{NO}_{3}{ }^{-}$no solo, reflexo da nitrificação. A mineralização da matéria orgânica supriu boa parte da necessidade de absorção de N pelas forrageiras estudadas, e a B. brizantha alterou a nitrificação em sua rizosfera, no entanto esse efeito não foi de magnitude suficiente para alterar o teor de $\mathrm{N}-\mathrm{NH}_{4}^{+}$presente no volume total de solo do vaso.
\end{abstract}

Termos de indexação: amônio, nitrato, nitrogênio.

\section{INTRODUCTION}

The low use efficiency of $\mathrm{N}$ fertilizers and the pollution potential arising from this inefficiency are major concerns in agriculture. Nitrogen leaching from the soil causes great economic losses, estimated at approximately 15 billion dollars annually, as well as environmental consequences, such as water pollution by nitrates, eutrophication and atmospheric pollution (Raun \& Johnson, 1999; Giles, 2005). In soils, ammonium $\mathrm{N}\left(\mathrm{N}_{-} \mathrm{NH}_{4}{ }^{+}\right)$can be transformed into nitrate $\mathrm{N}\left(\mathrm{N}^{-} \mathrm{NO}_{3}{ }^{-}\right)$through the activity of nitrifying bacteria in a process known as nitrification. Nitrification involves the transformation of a relatively immobile cation into a highly mobile anion. This transformation may result in high $\mathrm{N}$ loss through de-nitrification and/ or leaching of $\mathrm{N}^{-\mathrm{NO}_{3}}$ - (Subbarao et al., 2006a); eventually, nitrification can affect $\mathrm{N}$ use by plants (Raun \& Johnson, 1999; Glass, 2003; Giles, 2005; Subbarao et al., 2006a).

To minimize nitrification and reduce $\mathrm{N}$ loss in agricultural or pasture areas, it is necessary to maintain soil $\mathrm{N}$ in the form of $\mathrm{N}-\mathrm{NH}_{4}{ }^{+}$for as long as possible to synchronize $\mathrm{N}$ fertilizer supply and the plant demand (Ishikawa et al., 2003). Inhibiting nitrification and maintaining $\mathrm{N}$ in the form of ammonium may be a strategy for extending the residual time of $\mathrm{N}$ in the soil and increasing $\mathrm{N}$ recovery in the system and the efficiency of $\mathrm{N}$ usage (Rodgers, 1986).

Chemical inhibitors have been used to improve $\mathrm{N}$ use efficiency and reduce environmental pollution (Sahrawat \& Keeney, 1985; Prasad \& Power, 1995). However, in some ecosystems, there is evidence of the natural suppression of nitrification in the soil by root exudation of inhibitory compounds by certain species (Subbarao et al., 2006a). Recent studies suggested that the roots of several tropical grasses, such as Brachiaria humidicola, release a compound known as braquialactone that can reduce or suppress nitrification in soil (Subbarao et al., 2009).

Recently, systems attempting to reduce soil disturbance and maintain mulch on the soil surface have been increasingly adopted. Therefore, the importance of forage species as cover crops has increased because such plants are competitive and stress-tolerant. Furthermore, cover crops can serve as mulch producers of adequate quality for tropical regions. In this context, Silva et al. (2004) reported that species of the genus Brachiaria are frequently used in no-till systems because these plants are highly adaptable and tolerant to limiting conditions that would affect other forage species negatively. These grass species have been known since the 1950's in Brazil, but the actual acreage expansion occurred in the '70s and '80s, mainly in tropical regions. Of the genus Brachiaria, the species $B$. brizantha, $B$. ruziziensis and $B$. decumbens are the most widely used in Brazil (Zimer et al., 1995).

Due to the use of Brachiaria species as cover crops for mulch formation in no-till systems and the possibility that tropical grasses of the genus Brachiaria (e.g., B. humidicola) have the capacity of nitrification inhibition in soils, the aim of this study was to investigate the absorption of $\mathrm{N}$ by Brachiaria species and evaluate if other Brachiaria than B. humidicola are able to inhibit the nitrification process in soil.

\section{MATERIALS AND METHODS}

This study was conducted in a greenhouse of the Faculdade de Ciências Agronômicas, Botucatu, São Paulo State, from October to December 2008. Soil was collected from the surface layer $(0-20 \mathrm{~cm})$ of a typic dystrophic Red Latosol (Embrapa, 1999). The chemical characteristics of the soil were determined (Table 1), and the soil sieved through $4 \mathrm{~mm}$ mesh. Lime (PRNT $90 \%$ ) was applied to raise base saturation to $50 \%$ (Raij et al., 1996), and the soil was filled in $10 \mathrm{dm}^{3}$ plastic pots with closed-bottom. Together with liming, $150 \mathrm{mg} \mathrm{dm}^{-3} \mathrm{P}$ and $\mathrm{K}$ fertilizer were applied in the form of simple superphosphate and potassium chloride, respectively. The soil was then placed in a humid incubator at moisture levels close to its water-holding capacity for 15 days. After 
Table 1. Chemical characteristics before the experiment, and the concentrations of $\mathrm{N}_{-} \mathrm{NH}_{4}^{+}$and $\mathrm{N}-\mathrm{NO}_{3}^{-}$ after correction and incubation of the soil

\begin{tabular}{|c|c|c|c|c|c|c|c|c|c|}
\hline $\mathrm{pH} \mathrm{CaCl}_{2}$ & OM & $P_{\text {resin }}$ & $\mathbf{K}$ & $\mathrm{Ca}^{2+}$ & $\mathbf{M g}^{2+}$ & CEC & $\mathbf{V}^{(1)}$ & $\mathrm{N}-\mathrm{NH}_{4}^{+}$ & $\mathrm{N}-\mathrm{NO}_{3}^{-}$ \\
\hline & $\mathrm{g} \mathrm{dm}^{-3}$ & $\mathrm{mg} \mathrm{dm}^{-3}$ & \multicolumn{4}{|c|}{$-\mathrm{mmol}_{\mathrm{c}} \mathrm{dm}^{-3}$} & $\%$ & \multicolumn{2}{|c|}{$\longrightarrow \mathrm{mg} \mathrm{kg}^{-1}$} \\
\hline 4.1 & 18.0 & 3.0 & 0.2 & 2.0 & 1.0 & 75.0 & 4.0 & 6.79 & 7.49 \\
\hline
\end{tabular}

this period, a representative sample was air-dried and sampled for $\mathrm{N}-\mathrm{NH}_{4}{ }^{+}$and $\mathrm{N}-\mathrm{NO}_{3}{ }^{-}$determination according to Bremner \& Keeney (1966).

In this experiment a 4 × 4 factorial design was used in randomized blocks with four replications. The treatments consisted of three species (B. brizantha, $B$. ruziziensis and $B$. decumbens), one control (no plants) and four $\mathrm{N}$ rates (0, 100, 200 and $300 \mathrm{mg} / \mathrm{pot})$.

Seeds from the forage plants were pre-germinated in vermiculite-based substrate, and when they had grown 3 to 4 leaves (8 days after sowing), four seedlings were transferred to each pot. Fourteen days after initiating the experiment, the $\mathrm{N}$ treatments $(0$, 100,200 and $300 \mathrm{mg} /$ pot) were applied in the form of $\left.\mathrm{NH}_{4}\right)_{2} \mathrm{SO}_{4}$, balanced adequately with $\mathrm{S}$ additions. The moisture in the pots was daily monitored by weighing and was maintained at $~ 80$ to $100 \%$ of the soil waterholding capacity. Forty days after $\mathrm{N}$ application (40 DAN), the above-ground parts of the plants were collected, washed and dried to constant weight in a convection oven at $65^{\circ} \mathrm{C}$. The dry matter was then determined. After drying, all plant material was ground and the $\mathrm{N}$ concentration determined (Bremner $\&$ Keeney, 1966). The total $\mathrm{N}$ amount in the aboveground plant parts was calculated from the $\mathrm{N}$ concentration and dry weight mass data.

After plant collection, the soil from each pot was sampled, and the rhizosphere and non-rhizosphere soils were separated by gently agitation. Both samples were air-dried, and $\mathrm{N}-\mathrm{NH}_{4}{ }^{+}$and $\mathrm{N}-\mathrm{NO}_{3}{ }^{-}$were determined by steam distillation (Bremner \& Keeney, 1966). Differences among the initial and final $\mathrm{N}$ $\mathrm{NH}_{4}{ }^{+}, \mathrm{N}-\mathrm{NO}_{3}{ }^{-}$and inorganic $\mathrm{N}$ (i.e., the sum of $\mathrm{N}$ $\mathrm{NH}_{4}{ }^{+}$and $\mathrm{N}-\mathrm{NO}_{3}$ ) in each pot were calculated considering the fertilizer applied. From the $\mathrm{N}$ accumulation in the above-ground portions of the plants and the difference between the initial and final amounts of inorganic $\mathrm{N}$ in the soil, the amount of $\mathrm{N}$ absorbed by the plants that was supplied by OM mineralization was estimated.

The results were analyzed by ANOVA, and the means of the forage species were compared by the $t$ test $(p<0.05)$. Where appropriate, regressions were fit to $\mathrm{N}$ response. The calculations were performed with the statistical program Sisvar (Ferreira, 2000).

\section{RESULTS AND DISCUSSION}

In the absence of $\mathrm{N}$ fertilizers, the highest yield of above-ground dry matter was found in $B$. decumbens (Figure 1a), which may be related to the greater capacity of this species to adapt to soils with low $\mathrm{N}$ availability. In the experiments with medium $\mathrm{N}$ rates, $B$. brizantha had the highest yield, though it did not differ from $B$. decumbens at $200 \mathrm{mg} / \mathrm{pot}$ of $\mathrm{N}$. However, at a higher $\mathrm{N}$ rate $(300 \mathrm{mg} / \mathrm{pot})$, the different Brachiaria species did not result in different dry matter amounts (Figure 1a). An increase in $\mathrm{N}$ availability resulted in a linear increase in $B$. decumbens dry matter yields and quadratic growth of $B$. brizantha and $B$. ruziziensis, with the highest yields estimated at 248 and $297 \mathrm{mg} /$ pot of $\mathrm{N}$, respectively.

Although there was no difference among $\mathrm{N}$ concentrations in the above-ground forage plant parts (Figure 1b), N accumulated in the plants varied among the different $\mathrm{N}$ applications (Figure 1c). In the absence of $\mathrm{N}$ fertilizer, $B$. decumbens accumulated most $\mathrm{N}$, as shown by its higher dry matter yield (Figure 1a). In the pots with 200 and $300 \mathrm{mg} \mathrm{N}, \mathrm{N}$ uptake by $B$. brizantha and $B$. decumbens was similar, and in both cases higher than of $B$. ruziziensis (Figure 1c). However, the greatest $\mathrm{N}$ accumulation, achieved by $B$. brizantha and $B$. decumbens at the highest $\mathrm{N}$ rate (Figure 1c), was not reflected in the amounts of dry matter yields (Figure 1a). This shows that when $\mathrm{N}$ availability is not a limiting factor $B$. ruziziensis has a higher nutrient use efficiency, i.e., although lower amounts are extracted (Figure 1c), the dry matter yield of this species is similar to the others (Figure 1a).

After liming and fertilization, the soil had 67.9 and $74.9 \mathrm{mg} /$ pot of $\mathrm{N}-\mathrm{NH}_{4}{ }^{+}$and $\mathrm{N}-\mathrm{NO}_{3}{ }^{-}$, respectively (Table 1). Hence, $\mathrm{N}$ application in the form of $\mathrm{N}_{-} \mathrm{NH}_{4}{ }^{+}$ caused small increases in the soil N- $\mathrm{NH}_{4}{ }^{+}$levels, in the control treatment (no plants). However, the lowest levels of $\mathrm{N}-\mathrm{NH}_{4}{ }^{+}$(Figure 2a) and the highest levels of $\mathrm{N}-\mathrm{NO}_{3}^{-}$(Figure $2 \mathrm{~b}$ ) were observed in this treatment, confirming the presence and activity of nitrifying bacteria in the soil.

Highest $\mathrm{N}-\mathrm{NO}_{3}{ }^{-}$levels were observed in the soil cultivated with $B$. ruziziensis, most likely due to a 

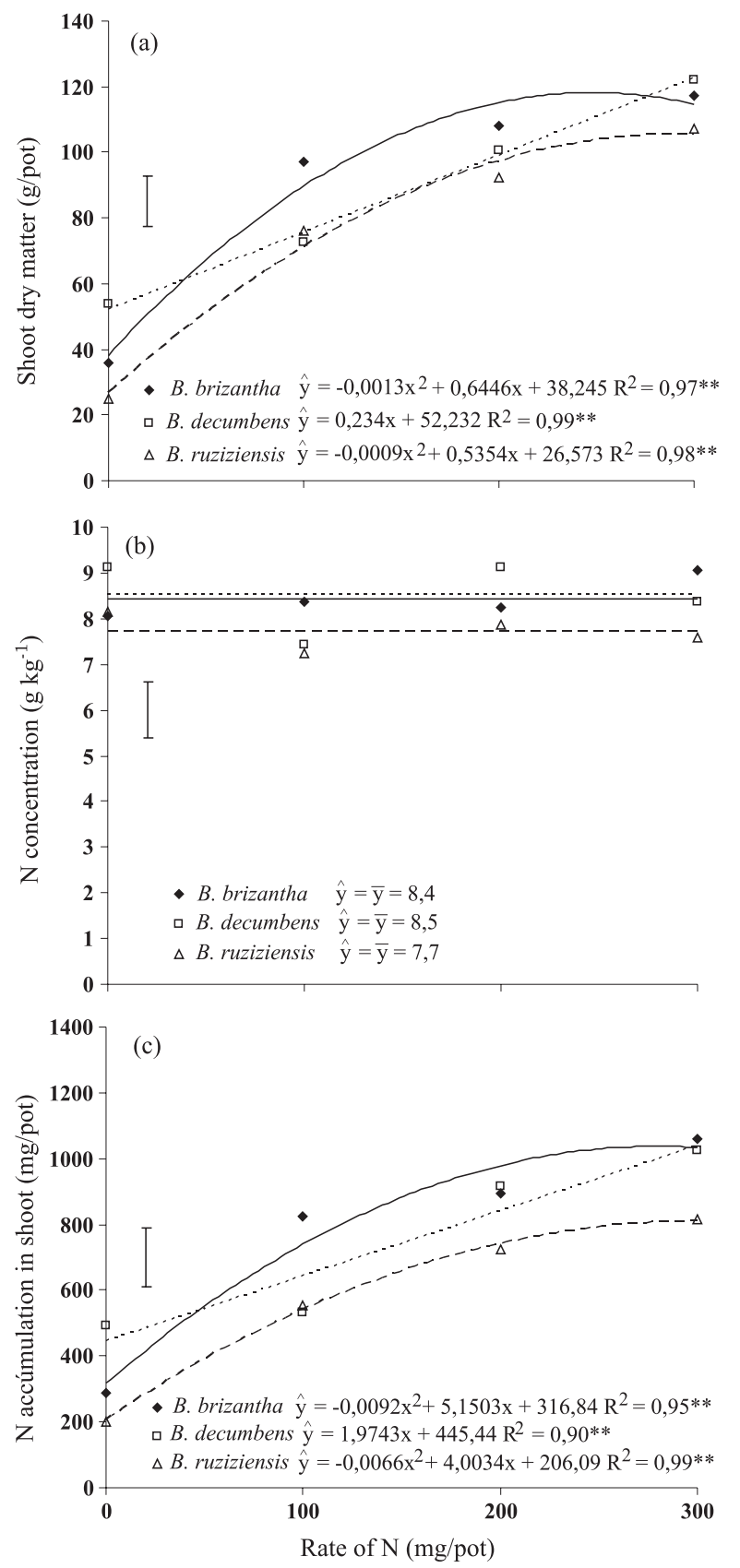

Figure 1. Dry matter of the shoot (a), concentration (b) and nitrogen accumulation (c) in shoots of Brachiaria species, as affected by $\mathrm{N}$ rates, 40 days after the application. * and ** significant at $5 \%$ and $1 \%$ by the $\mathrm{F}$ test; Vertical bars indicate the Least Significant Difference (LSD) at $5 \%$.

lower N-NH ${ }_{4}{ }^{+}$absorption and consequently lower $\mathrm{N}$ extraction by this species (Figure 1c), because the $\mathrm{N}$ $\mathrm{NO}_{3}$ - level in the soil was similar for all species, except at the highest dose. At the highest rate, the $\mathrm{N}^{-\mathrm{NO}_{3}}$ level in the soil with $B$. ruziziensis remained lower than in the soils with $B$. decumbens (Figure $2 b$ ). It is noteworthy that the application of the highest $\mathrm{N}$ rate to $B$. decumbens and $B$. brizantha soils resulted in $\mathrm{N}-\mathrm{NH}_{4}{ }^{+}$levels similar to those of the soil without forage plants (Figure 2a). This is an evidence of the possibility of a greater absorption of $\mathrm{N}^{-\mathrm{NH}_{4}}{ }^{+}$than $\mathrm{N}$ $\mathrm{NO}_{3}{ }^{-}$by these two species. Given the similar levels of $\mathrm{N}-\mathrm{NH}_{4}{ }^{+}$under these conditions, we hypothesize that $\mathrm{N}-\mathrm{NH}_{4}{ }^{+}$nitrification was increased, because the $\mathrm{N}$ $\mathrm{NO}_{3}{ }^{-}$levels in the soils with these forage plants were greater than those observed when B. ruziziensis was grown (Figure 2b). Carmo et al. (2005) studied the flow of $\mathrm{N}_{2} \mathrm{O}$ in soils from pastures and forests and found that in a pasture where a mixture of $B$. brinzantha and Panicum maximum was grown, the $\mathrm{N}-\mathrm{NH}_{4}{ }^{+}$level in the soil was always greater than of $\mathrm{N}-\mathrm{NO}_{3}{ }^{-}$(4.6 and $2.41 \mathrm{mg} \mathrm{kg}^{-1}$, respectively). In forest soils, these authors obtained similar values of $4.83 \mathrm{mg} \mathrm{kg}^{-1}$ for $\mathrm{N}^{-\mathrm{NH}_{4}}{ }^{+}$and $4.21 \mathrm{mg} \mathrm{kg}{ }^{-1}$ for $\mathrm{N}^{-\mathrm{NO}_{3}}{ }^{-}$ at equilibrium. However, this does not indicate nitrification inhibition because the pasture may have absorbed less $\mathrm{N}-\mathrm{NH}_{4}{ }^{+}$.

Based on the difference between the initial and final quantities of $\mathrm{N}-\mathrm{NH}_{4}{ }^{+}$(Figure 3a) and $\mathrm{N}-\mathrm{NO}_{3}{ }^{-}$ (Figure $3 \mathrm{~b}$ ) in the pots, the amount of $\mathrm{N}$ removed by

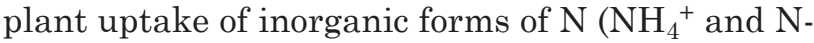
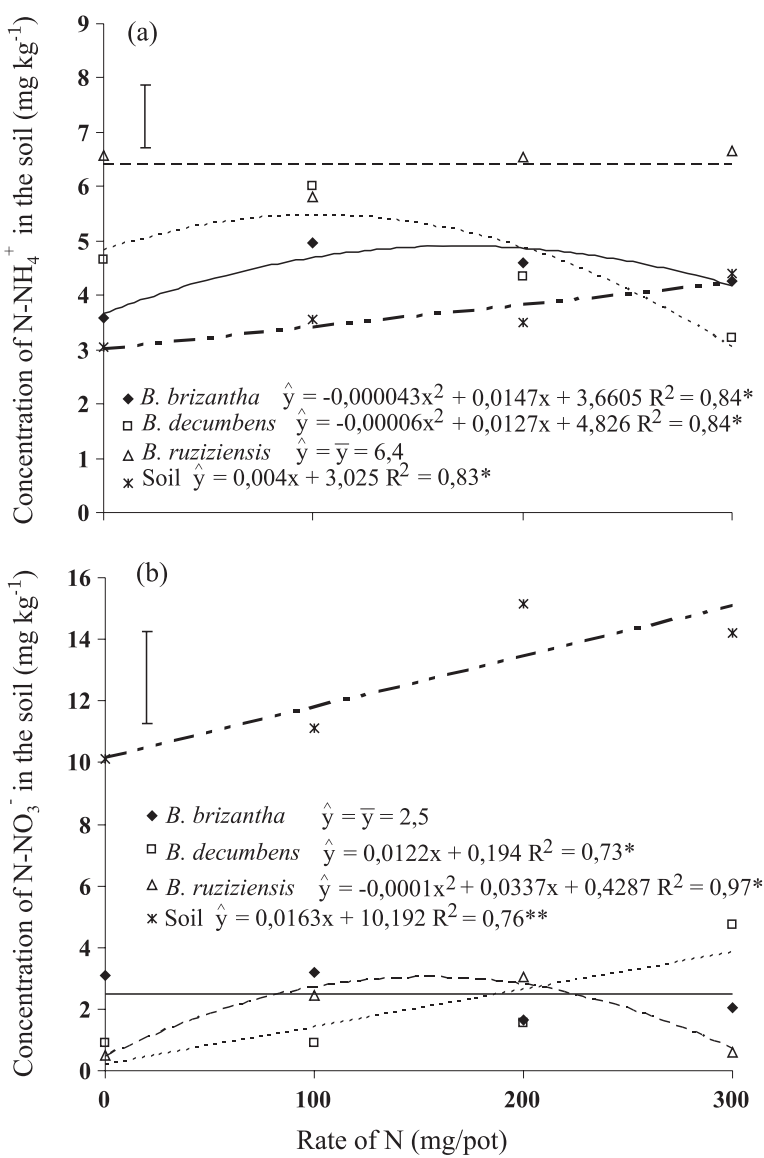

Figure 2. Concentration of $\mathrm{N}^{-} \mathrm{NH}_{4}^{+}$(a) and $\mathrm{N}_{-} \mathrm{NO}_{3}{ }^{-}$(b) in the soil as affected by $\mathrm{N}$ rates and Brachiaria species, 40 days after the application. * and $* *$ significant at $5 \%$ and $1 \%$ by the $F$ test; Vertical bars indicate the Least Significant Difference (LSD) at $5 \%$. 
$\mathrm{NO}_{3}{ }^{-}$) and/or transformed by the process of $\mathrm{N}-\mathrm{NH}_{4}{ }^{+}$ nitrification (transformation of $\mathrm{N}-\mathrm{NH}_{4}{ }^{+}$into $\mathrm{N}-\mathrm{NO}_{3}{ }^{-}$) was determined. Increases in $\mathrm{N}^{-\mathrm{NO}_{3}}{ }^{-}$in the soils without forage plants were attributed to nitrification. In the absence of $\mathrm{N}$ fertilizer and with the application of 200 and $300 \mathrm{mg} / \mathrm{pot} \mathrm{N}$, the amount of $\mathrm{N}-\mathrm{NH}_{4}$ absorbed and/or nitrified in $B$. ruziziensis soil was
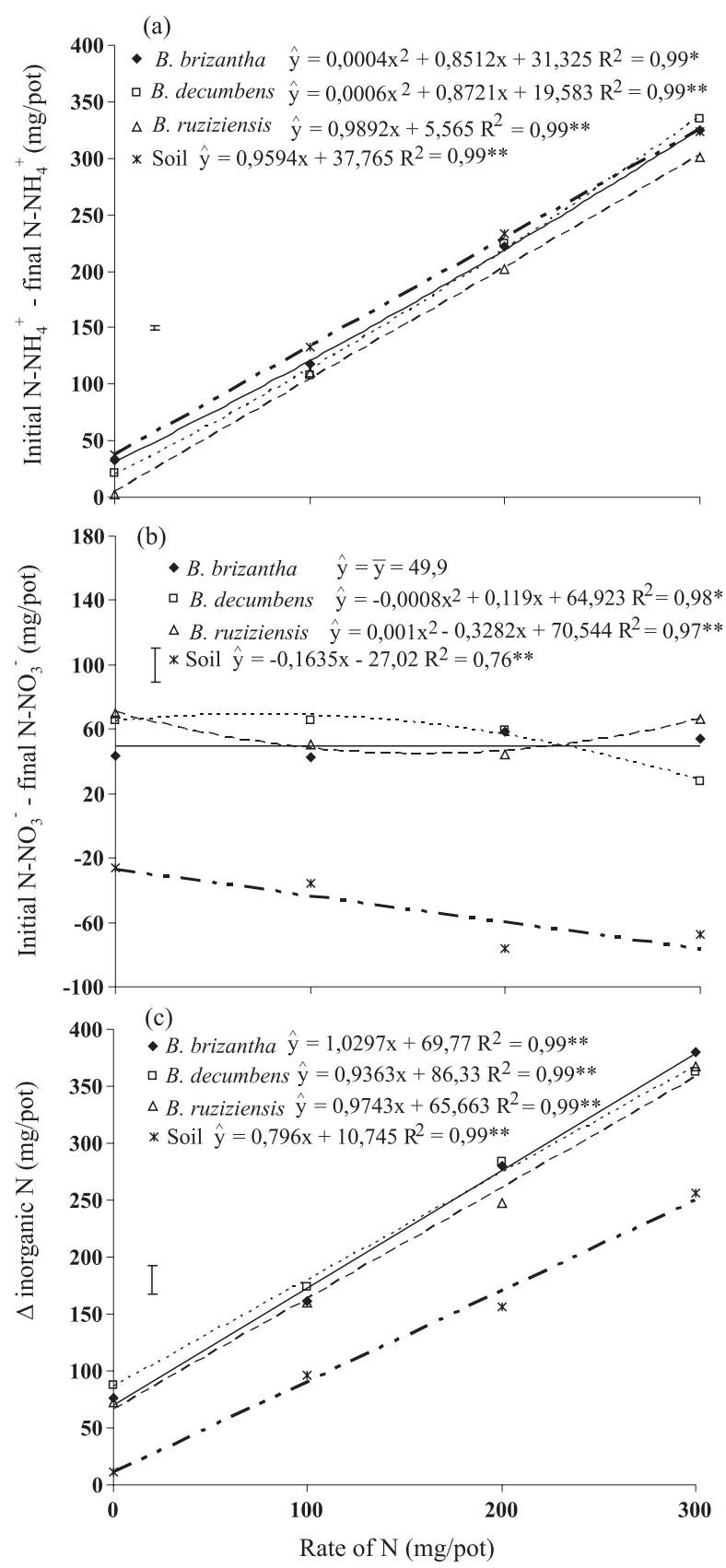

Figure 3. Difference $(\Delta)$ between the initial and final $\mathrm{N}-\mathrm{NH}_{4}^{+}(\mathrm{a})$; initial and final $\mathrm{N}-\mathrm{NO}_{3}{ }^{-}(\mathrm{b})$ and initial and of inorganic $\mathrm{N}\left(\mathrm{N}-\mathrm{NH}_{4}{ }^{+}\right.$and $\left.\mathrm{N}-\mathrm{NO}_{3}{ }^{-}\right)$(c) as a function of $\mathrm{N}$ rates and Brachiaria species, 40 days after application. * and $* *$ significant at $5 \%$ and $1 \%$ by the $F$ test; Vertical bars indicate the Least Significant Difference (LSD) at $5 \%$. less than that obtained in the soil with other forage plants (Figure 3a), which is explained by the higher level of $\mathrm{N}-\mathrm{NH}_{4}{ }^{+}$in the soil of this treatment at the end of the experiment (Figure 2a). The greatest difference between the initial and final amounts of $\mathrm{N}$ $\mathrm{NH}_{4}{ }^{+}$in the soil was found in the control treatment (Figure 3a) due to lower $\mathrm{N}-\mathrm{NH}_{4}{ }^{+}$concentrations in the soil at the end of the experiment (Figure 2a). However, $\mathrm{N}-\mathrm{NO}_{3}-$ uptake was similar, except at the highest $\mathrm{N}$ rate (Figure $3 \mathrm{~b}$ ), which reflects the $\mathrm{N}_{-} \mathrm{NO}_{3}$ concentrations obtained in these treatments (Figure 2b). However, it was clear that nitrification occurred in the soil without forage plants because the final $\mathrm{N}-\mathrm{NO}_{3}{ }^{-}$concentrations in the control treatment were greater than the initial levels (Figure $3 b$ ). It was also evident that with an increase in $\mathrm{N}$ availability in the form of $\mathrm{N}^{-\mathrm{NH}_{4}}{ }^{+}$provided by fertilization, nitrification increased and resulted in greater differences between the initial and final $\mathrm{N}-\mathrm{NO}_{3}$ - levels (Figure 3b).

However, when inorganic $\mathrm{N}\left(\mathrm{N}-\mathrm{NH}_{4}{ }^{+}\right.$and $\left.\mathrm{N}-\mathrm{NO}_{3}{ }^{-}\right)$ was considered (Figure 3c), there was no significant difference in $\mathrm{N}$ absorption among the species. Still, loss of $\mathrm{N}$ by volatilization probably occurred in the treatment without plants because there were no plants present to absorb the N. These losses were insignificant when no $\mathrm{N}$ was applied, but losses by volatilization increased as $\mathrm{N}$ availability increased.

In general, with the exception of $B$. ruziziensis, we observed that $\mathrm{N}-\mathrm{NH}_{4}{ }^{+}$concentrations in the soil (Figure 2a) were lower than in the rhizosphere (Figure 4a). However, there were no differences among the $\mathrm{N}-\mathrm{NH}_{4}{ }^{+}$concentrations in the rhizosphere of the different species as a function of fertilization (Figure 4a). Nevertheless, differences were observed among the species for all applied $\mathrm{N}$ rates, except for $B$. decumbens and B. ruziziensis at the highest rate (Figure 4b). Furthermore, lower $\mathrm{N}_{-} \mathrm{NO}_{3}$ concentrations in the rhizospheric soil were obtained when $B$. brizantha was grown. It can be concluded that a $\mathrm{N}$ concentration gradient was created near the root surface through the $\mathrm{N}$ uptake by $B$. brizantha, which was reflected by a lower $\mathrm{N}-\mathrm{NO}_{3}{ }^{-}$level in the rhizospheric region. Another factor that may have contributed to the lower $\mathrm{N}-\mathrm{NO}_{3}^{-}$level in this environment is the inhibition of the biological process of nitrification by $B$. brizantha in the rhizosphere.

In a comparative study of various forage species (Melinis minutiflora, Andropogon gayanus, B. decumbens, and $B$. humidicola) grown in acidic soils in Colombia, lower $\mathrm{N}-\mathrm{NO}_{3}$ - concentrations were only found in soils under B. humidicola (Sylvester-Bradley et al., 1988). This is one of the first indications of a possible nitrification inhibition by $B$. humidicola when compared to other forage species such as $B$. decumbens. The results of this study provide strong evidence that $B$. decumbens and B. ruziziensis are not capable of inhibiting nitrification in the rhizosphere. Researchers such as Sylvester-Bradley 


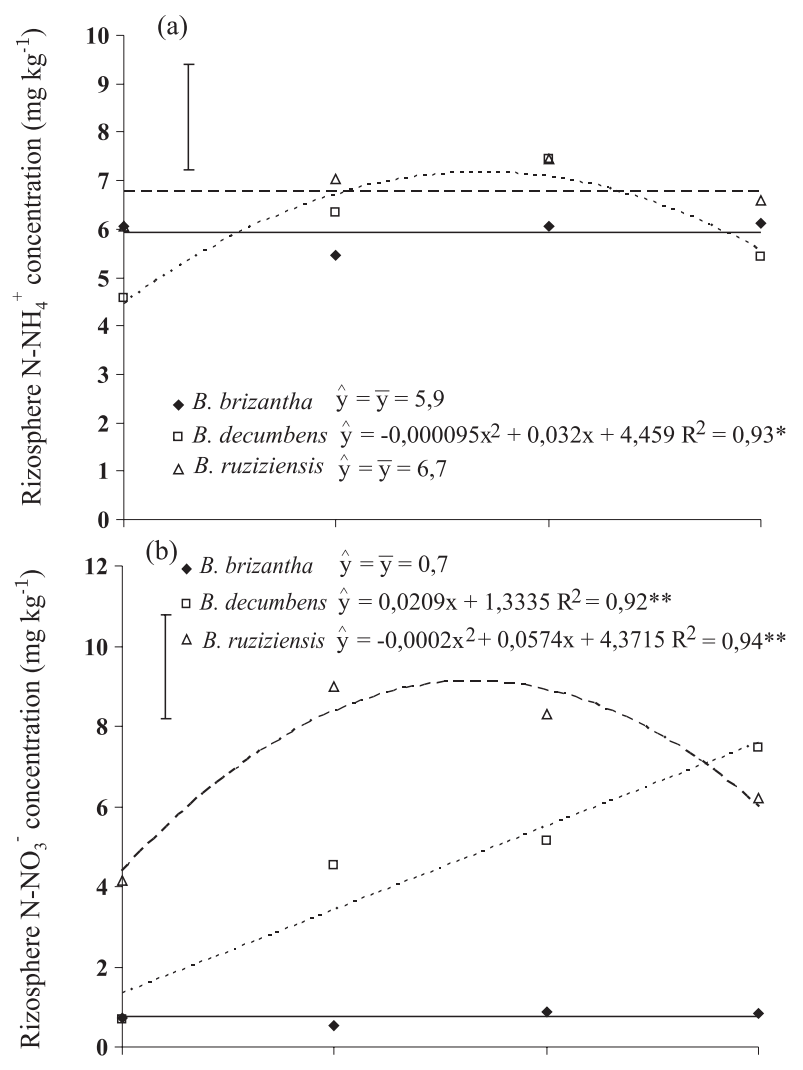

(c)

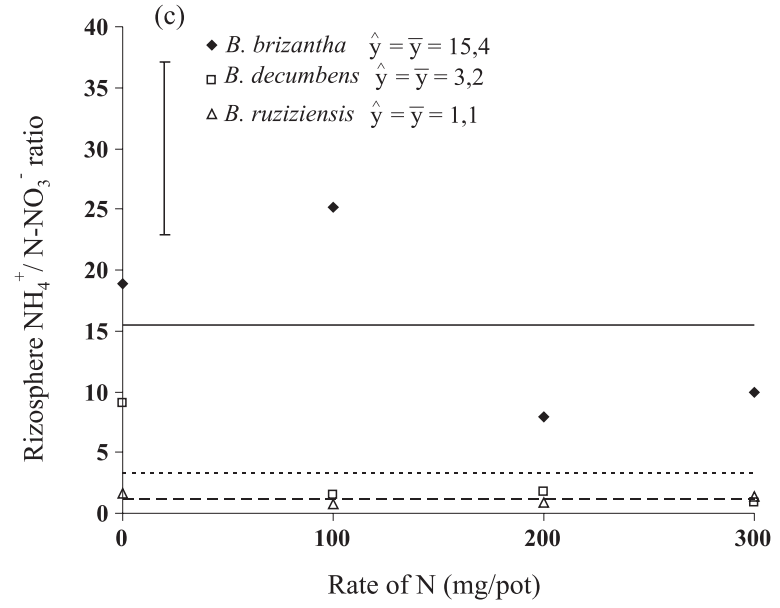

Figure 4. Concentration of $\mathrm{N}-\mathrm{NH}_{4}{ }^{+}(\mathrm{a}) ; \mathrm{N}^{-} \mathrm{NO}_{3}{ }^{-}(\mathrm{b})$ and ratio of $\mathrm{N}-\mathrm{NH}_{4}{ }^{+} / \mathrm{N}^{-\mathrm{NO}_{3}}{ }_{3}^{-}$(c) in the rhizosphere of forage plants as affected by $\mathrm{N}$ rates and Brachiaria species, 40 days after the application. * and $* *$ significant at $5 \%$ and $1 \%$ by the $\mathrm{F}$ test; Vertical bars indicate the Least Significant Difference (LSD) at $5 \%$.

et al. (1988) and Ishikawa et al. (2003) also observed that $B$. decumbens does not have the same ability to inhibit nitrification as reported for B. humidicola (Ishikawa et al., 2003; Subbarao et al., 2006b,a). Ishiwawa et al. (2003) confirmed that B. humidicola is able to suppress nitrification and maintain $\mathrm{N}$ in the soil in the form of $\mathrm{N}_{-} \mathrm{NH}_{4}{ }^{+}$. They also observed that the effect of suppression on the ammonia-oxidizing bacteria population lasted up to 12 days after plant collection, suggesting that the effect of nitrification inhibition is long-lasting when plants are in the soil. A possible mechanism for the suppression of nitrifying bacterial populations could be root exudates.

According to Subbarao et al. (2007a), nitrification inhibition occurs through the release of root compounds by tropical pastures, inhibiting the microorganisms responsible for nitrification. These authors observed that plants treated with $\mathrm{N}-\mathrm{NH}_{4}{ }^{+}$ released almost three times more biological nitrification-inhibiting compounds than plants grown with $\mathrm{N}_{-} \mathrm{NO}_{3}$. These compounds exert an inhibitory effect on two enzymes involved in the nitrification process of Nitrossomonas europae, a species used in their studies. Subbarao et al. (2007b) also observed that other domesticated species have the capacity to produce biological nitrification-inhibiting compounds in quantities sufficient to block nitrification in the soil. Among the species with this ability are sorghum (Sorghum bicolour), pearl millet (Pennisetum glaucum) and peanuts (Arachis hypogaea).

The hypothesis about nitrification inhibition in the rhizosphere by root exudates is strengthened by the fact that virtually no statistical differences among the species were found in the quantity of $\mathrm{N}_{-} \mathrm{NH}_{4}{ }^{+}$absorbed and/or nitrified (Figure 3a), the quantity of $\mathrm{N}^{-\mathrm{NO}_{3}}$ absorbed (Figure $3 \mathrm{~b}$ ) or the total quantity of inorganic $\mathrm{N}$ absorbed from the pots (Figure 3c). Furthermore, the highest $\mathrm{N}-\mathrm{NH}_{4}{ }^{+} / \mathrm{N}-\mathrm{NO}_{3}-$ ratio present in the rhizosphere of $B$. brizantha was on average $15 / 1$, but $3 / 1$ and $1 / 1$ for $B$. decumbens and B. ruziziensis, respectively (Figure $4 \mathrm{c}$ ). This proves that $B$. brizantha had an inhibitory effect on nitrification in the rhizosphere although the effect was small and not expressed as difference in the levels and extracted quantities of $\mathrm{N}^{-\mathrm{NO}_{3}}{ }^{-}$and $\mathrm{N}-\mathrm{NH}_{4}{ }^{+}$in the total soil volume in the pots. The quantity of $\mathrm{N}$ mineralized from the organic matter was another factor that contributed to the make the plant response to nitrification inhibition undetectable in the total soil volume of the pots (Figure 5). In the pots where no nitrogen fertilizer had been applied, 82, 73 and $64 \%$ of the total $\mathrm{N}$ absorbed by $B$. decumbens, $B$. brizantha and $B$. ruziziensis, respectively (Figure 1c), was from the mineralization of organic matter (Figure 5). At the highest $\mathrm{N}$ rate, organic matter mineralization was still sufficient to provide approximately $64 \%$ of $\mathrm{N}$ taken up by B. brizantha and B. decumbens and $54 \%$ of $\mathrm{N}$ absorbed by $B$. ruziziensis (Figure 5). In another pot experiment, Subbarao et al. (2007b) observed that the majority of inorganic $\mathrm{N}$ in the soil at the end of 30 days of incubation came from the mineralization of organic N. This phenomenon is likely to have occurred in the current study as well. The mineralization of organic $\mathrm{N}$ from the soil is stimulated by the addition of organic material, which is rich in energy, or the addition of $\mathrm{N}$ fertilizers. This effect is 
known as "priming," or the effect of added N. The amount of energy or nutrients added stimulates the microbial flora to attack the organic material in the soil so that mineral $\mathrm{N}$ exceeds the $\mathrm{N}$ quantity that would be released without the addition of these inputs (Cantarela, 2007). Gross mineralization occurs at 2 to $3 \mathrm{mg} \mathrm{kg}^{-1} \mathrm{day}^{-1}$ (Addiscott, 2004). Moreover, differences were observed among the species studied in terms of the amount of $\mathrm{N}$ mineralized from organic material; B. decumbens and B. brizantha experienced more mineralization at the lowest and highest $\mathrm{N}$ rates (Figure 5). This observation reinforces the hypothesis that the mineralization of organic material provided most of the $\mathrm{N}$ absorbed by $B$. brizantha, which only permitted the observation of differences between quantities of $\mathrm{N}-\mathrm{NH}_{4}{ }^{+}$and $\mathrm{N}-\mathrm{NO}_{3}-$ in the rhizosphere, but not in the total soil volume in the pot.

Therefore, in this study, the mineralization of organic matter suppressed much of the $\mathrm{N}$ uptake requirement by the forage plants, and the small effect of $B$. brizantha on nitrification in the rhizosphere was not strong enough to cause a change in the $\mathrm{N}-\mathrm{NH}_{4}{ }^{+}$ level in the total soil volume in the pot or in the amount of $\mathrm{N}$ absorbed and/or nitrified in the entire pot environment.

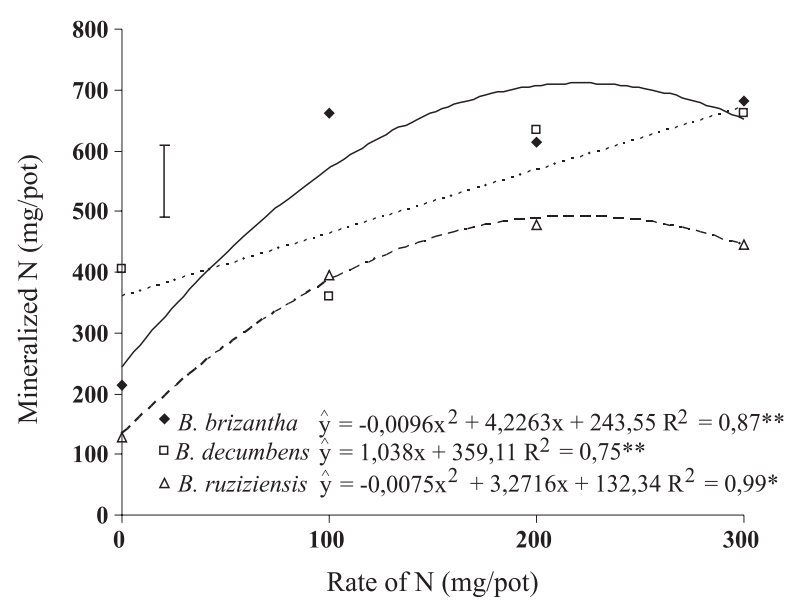

Figure 5. Nitrogen mineralized in soil, as affected by $\mathrm{N}$ rates and Brachiaria species, 40 days after the application. * and ** significant at $5 \%$ and $1 \%$ by the $F$ test; Vertical bars indicate the Least Significant Difference (LSD) at $5 \%$.

\section{CONCLUSIONS}

1. Organic matter mineralization in the soil may provide $>50 \%$ of the total $\mathrm{N}$ absorbed by the forage plants studied, even when $\mathrm{N}$ fertilizers are applied.

2. Growing Brachiaria species reduces the $\mathrm{N}-\mathrm{NO}_{3}$ level in the soil, independently of the $\mathrm{N}$ rate, whereas the $\mathrm{N}-\mathrm{NH}_{4}{ }^{+}$level is increased, principally at lower $\mathrm{N}$ rates.
3. Inhibition of nitrification by $B$. brizantha is restricted to the rhizosphere and does not affect the levels and quantities of $\mathrm{N}-\mathrm{NO}_{3}{ }^{-}$and $\mathrm{N}-\mathrm{NH}_{4}{ }^{+}$in the total soil volume.

\section{LITERATURE CITED}

ADDISCOTT, T.M. Nitrate, agriculture and the environment. Wallingford, CABI Publishing, 2004. 279p.

BREMNER, J.M. \& KEENEY, D.R. Determination and isotope-ratio analysis of different forms of nitrogen in soils: 3. Exchangeable ammonium, nitrate, and nitrite by extraction-distillation methods. Soil Sci. Soc. Am. Proc., 30:577-582, 1966

CANTARELLA, H. Nitrogênio. In: NOVAIS, R.F.; ALVAREZ V., V.H.; BARROS, N.F.; FONTES, R.L.F.; CANTARUTTI, R.B. \& NEVES, J.C.L., ed. Fertilidade do solo. Viçosa, MG, Sociedade Brasileira de Ciência do Solo, 2007. p.382395.

CARMO, J.B.; ANDRADE, C.A.; CERRI, C.C. \& PICCOLO, M.C. Disponibilidade de nitrogênio e fluxos de $\mathrm{N}_{2} \mathrm{O}$ a partir de solo sob pastagem após aplicação de herbicida. R. Bras. Ci. Solo, 29:735-746, 2005.

EMPRESA BRASILEIRA DE PESQUISA AGROPECUÁRIA EMBRAPA. Centro Nacional de Pesqisa do Solo. Sistema brasileiro de classificação de solos. Brasília, Embrapa/ CNPSO, 1999. 412p.

FERREIRA, D.F. Manual do sistema sisvar para análise estatística. Lavras, Universidade Federal de Lavras, 2000. 63p.

GILES, J. Nitrogen study fertilizers fears of pollution. Nature, 433:791, 2005.

GLASS, A.D.M. Nitrogen use efficiency of crop plants: Physiological constraints upon nitrogen absorption. Crit. Rev. Plant Sci., 22:453-470, 2003.

ISHIKAWA, T.; SUBBARAO, G.V.; ITO, O. \& OKADA, K. Suppression of nitrification and nitrous oxide emission by the tropical grass Brachiaria humidicola. Plant Soil, 255:413-419, 2003.

PRASAD, R. \& POWER, J.F. Nitrification inhibitors for agriculture, health, and the environment. Adv. Agron., 54:233-281, 1995

RAIJ, B. van.; CANTARELLA, H.; QUAGGIO, J.A. \& FURLANI, A.M.C. Recomendações de adubação e calagem para o Estado de São Paulo. Campinas, Instituto Agronômico \& Fundação IAC, 1996. 285p.

RAUN, W.R. \& JOHNSON, G.V. Improving nitrogen use efficiency for cereal production. Agron. J., 91:357-363, 1999.

RODGERS, G.A. Nitrification inhibitors in agriculture. J. Environ. Sci. Heal., Part A, 21:701-722, 1986.

SAHRAWAT, K.L. \& KEENEY, D.R. Perspectives for research on development of nitrification inhibitors. Comm. Soil Sci. Plant Anal., 16:517-524, 1985. 
SILVA, A.C.; FERREIRA, L.R. \& SILVA, A.A. Efeitos de doses reduzidas de fluazifop-p-butil no consórcio entre soja e Brachiaria brizantha. Planta Daninha, 22:429-435, 2004.

SUBARAO, G.V.; NAKAHARA, K.; HURTADO, M.P.; ONO, H.; MORETA, D.E.; SALCEDO, A.F.; YOSHIHASHI, A.T.; ISHIKAWA, T.; ISHITANI, M.; OHNISHI-KAMEYAMA, M.; YOSHIDA, M.; RONDON, M.; RAO, I.M.; LASCANO, C.E.; BERRY, W.L. \& ITO, O. Evidence for biological nitrification inhibition in Brachiaria pastures. PNAS, 25:1 6, 2009.

SUBBARAO, G.V.; WANG, H.Y.; ITO, O.; NAKAHARA, K. \& BERRY, W.L. $\mathrm{NH}_{4}{ }^{+}$triggers the synthesis and release of biological nitrification inhibition compounds in Brachiaria humidicula roots. Plant Soil, 290:245-257, 2007a.

SUBBARAO, G.V.; ITO, O.; SAHRAWAT, K.L.; BERRY, W.L.; NAKAHARA, K.; ISHIKAWA, T.; WATANABE, T.; SUENAGA, K.; RONDON, M. \& RAO, I.M. Scope and strategies for regulation of nitrification in agricultural systems - challenges and opportunities. Crit. Rev. Plant Sci., 25:303-335, 2006a.
SUBBARAO, G.V.; ISHIKAWA, T.; ITO, O.; NAKAHARA, K.; WANG, H.Y. \& BERRY, W.L. A bioluminescence assay to detect nitriûcation inhibitors released from plant roots: a case study with Brachiaria humidicola. Plant Soil, 288:101-112, 2006b.

SUBBARAO, G.V.; RONDON, M.; ITO, O.; ISHIKAWA, T.; RAO, I.M.; NAKAHARA, K.; LASCANO, C. \& BERRY, W.L. Biological nitrification inhibition (BNI) - is it a widespread phenomenon? Plant Soil, 294:5-18, 2007b.

SYLVESTER-BRADLEY, R.; MOSQUERA, D. \& MENDEZ, J.E. Inhibition of nitrate accumulation in tropical grassland soil: Effect of nitrogen fertilization and soil disturbance. Europ. J. Soil Sci., 39:407-416, 1988.

ZIMMER, A.H.; EUCLIDES, V.P.B. \& MACEDO, M.C.M. Manejo de plantas forrageiras do gênero Brachiaria. In: PEIXOTO, A.M.; MOURA, J.C. \& FARIA, V.P., ed. Plantas forrageiras de pastagens. Piracicaba, FEALQ, 1995. p.101143. 